ÉGYPTE monde arabe

\section{Égypte/Monde arabe}

$14 \mid 2016$

Le Soudan, cinq ans après l'indépendance du Soudan du Sud

\title{
Thriving on chaos: the war in Darfur and the transformation of the authoritarian coalition
}

\section{Anne-Laure Mahé}

\section{(2) OpenEdition}

\section{Journals}

Electronic version

URL: https://journals.openedition.org/ema/3590

DOI: 10.4000/ema.3590

ISSN: 2090-7273

Publisher

CEDEJ - Centre d'études et de documentation économiques juridiques et sociales

Printed version

Date of publication: 21 October 2016

Number of pages: 137-154

ISBN: 2-905838-88-4

ISSN: 1110-5097

Electronic reference

Anne-Laure Mahé, "Thriving on chaos: the war in Darfur and the transformation of the authoritarian coalition", Égypte/Monde arabe [Online], 14 | 2016, Online since 21 October 2018, connection on 07 July 2022. URL: http://journals.openedition.org/ema/3590 ; DOl: https://doi.org/10.4000/ema.3590 
Anne- Laure Mahé

\title{
THRIVING ON CHAOS
}

\author{
THE WAR IN DARFUR AND THE TRANSFORMATION \\ OF THE AUTHORITARIAN COALITION
}

\begin{abstract}
A uthoritarian regimes are often considered to be prone to civil wars because they are fundamentally based on principles of marginalization and coercion. Recent literature on authoritarian resiliency tends nonetheless to consider that regimes that are plagued with violence cannot endure over the long term. Building on an analysis of Omar al-Bashir's regime in Sudan, this paper explores the relationship between civil wars and the winning coalition, the group of people whose loyalty is necessary for the survival of the regime. It studies the way in which the war in Darfur has been fought, and demonstrates how this has led to changes within the coalition that may contribute to the entrenchment of authoritarianism in Sudan.
\end{abstract}

In May 2008, for the first time in the history of Sudan, a rebel movement reached the gates of the capital city. Darfur's Justice and Equality Movement (JEM) had brought the war from the periphery to the economic and political centre of the country. The assault was pushed back, but it was nonetheless a sign that a regime that had long seemed unshakeable might actually be weaker than had previously been thought.

The current regime was established in June 1989, following a coup d'état orchestrated by the National Islamic Front (NIF) and carried out by a faction of army officers, among whom was Omar al-Bashir. It was only after a few weeks, however, that Sudanese and foreign observers alike understood the major role played by the Islamists, who were led by Hassan al-Turabi. The newly-established regime did not shy away from using violence. People were forced out of 
their jobs, demonstrations at the University of Khartoum were repressed, and most importantly, the secret services were reformed. This organization, which was initially renamed IS-SOR and is now known as the NISS, became one of the cornerstones of the regime's rule, and the infamous "ghost houses", secret prisons where opponents were sent to be killed and/or tortured, were created (International Crisis Group 2011: 60). Those early years of violence have left an enduring legacy among the Sudanese, especially as the regime has been careful to demonstrate its ruthlessness time and time again ${ }^{1}$.

Adding to this form of political violence, the war was also reignited in the country's provinces in the south and east and in the western province of Darfur. While their root causes are complex, and can sometimes be found in local disputes, there is little doubt that these conflicts are the consequence of a mixture of economic and political marginalization, with an added layer of cultural discrimination and racism arising from the regime's policies of Islamization and Arabization ${ }^{2}$. Indeed, Omar al-Bashir's government has long been accused of fuelling these wars while carefully protecting its backbone, which is Khartoum and the nether riverine regions from which most of Sudan's elites have come since independence in 1956. In the end, conflicts come and go in Sudan one after the other, but still Bashir stands strong in Khartoum, and his re-election in April 2015, although plagued by suspicions, has confirmed his grip on power.

That said, his longevity in the face of adversity from a multiplicity of rebel groups is rather odd, especially since many of them have identified the regime as the source of Sudan's problems, both political and economic. It was, for instance, the main topic of the mysterious "Black Book", whose writers called themselves 'The Seekers of Truth and Justice', which was disseminated around Khartoum in 2010. It contains an abundance of data and facts about the marginalization of every periphery in the country (Flint and de Waal 2008: 16), echoing the "New Sudan" discourse that was propagated by the Sudan People's Liberation Movement/Army (SPLM/A), the main southern rebel movement, although it eventually turned its back on it when it signed the Comprehensive Peace Agreement (CPA) in 2005. Despite its name, the CPA did not include any rebel movements from Darfur, or from anywhere else for that matter.

In this article, I question the relationship between civil wars and authoritarian resilience. I attempt to go beyond the notion that these wars are threats that the regime must overcome in order to survive, and follow De Waal in exploring the existence of structured governance systems in areas and times of turbulence (de Waal 2016). Looking at the transformative effects of the war

1. In September 2013, the regime violently repressed demonstrations in the country's main cities. In Khartoum, the security forces reportedly killed more than 200 people. 2. Policies such as these had also been implemented by previous regimes, but they have been intensified under al-Bashir's rule. 
on the "winning coalition" (de Mesquita and al. 2005), the small group whose loyalty keeps the autocrat in power, I argue that civil wars provide autocrats with opportunities. More specifically, they represent a moment when autocrats can find and groom new members of their coalitions in a way that entrenches their power. To develop this argument, I focus on the war in Darfur, and rely on both preliminary data collected during a field trip in Khartoum in early 2015 and secondary sources. Interviews were conducted with Darfuri officials, members of the opposition parties, and rebel movements, as well as with civil society actors. Research conducted in authoritarian contexts faces specific challenges, such as limitations on what informants are able to say without taking risks. It was therefore necessary to gain the interviewees' trust, for instance by ensuring the anonymity of the process, and to accept rejection, but also to interpret silences and contradictions during the interviews. Another way to improve the quality of the data has been through triangulation, using information that had been provided during other interviews or from secondary sources. Within these limitations, the primary aim of this article is to explore an argument that may provide an answer to a specific theoretical and empirical puzzle.

The paper is divided into three parts. The first offers a brief review of the literature on the relationship between war and authoritarian regimes, and discusses how the notion of the winning coalition can be used to comprehend the mechanisms that connect them. The second looks at way the war has proceeded, and introduces a new central actor, the Janjaweed. The last explores the impact of the inclusion of this actor on the regime's strategy, focusing on its function within the broader security apparatus. The paper concludes with some remarks that question whether the allies the regime has groomed in this context are really supportive of it, as there are no unequivocal allies in Sudan.

\section{INVESTIGATING THE FACTORS OF AUTHORITARIAN RESILIENCY: WAR AND THE WINNING COALITION}

\section{War in the study of authoritarianism}

The literature is rather indecisive on the issue of the relationship between civil wars and authoritarian resilience, which relates on a broader level to the question of the use of violence. The recent renewal of interest in research on the topic of authoritarianism, which has been focused mostly on the role of nominally democratic institutions, has set aside the question of the use of violence. This decision has been justified by the idea that authoritarianisms after the third wave of democratization are qualitatively different from their predecessors. For many researchers, authoritarianism has transformed itself to respond to the challenge of the spread of the democratic norm, leading to the appearance of what have been coined "hybrid" regimes, which mix democratic and authoritarian 
traits (Carothers 2002, Diamond 2002, Levitsky and Way 2002). Furthermore, these regimes are starkly distinct from the forms of extreme personalization of power - such as those practiced by Idi Amin Dada and Jean-Bedel Bokassa that were common during the immediate post-independence period. There are also nowadays fewer military regimes, which used to be the most common type of non-democratic system (Tripp 2004). These regimes were characterized by their use of violence, an area in which they possessed a comparative advantage (Fjelde 2010). According to Tripp (2004), authoritarianism has softened, and Picard (2008) seems to concur when she writes that most autocrats seek to avoid using violence, instead implementing strategies aimed at internalization of the balance of power. Analyses of authoritarianism have therefore moved away from definitions that postulate an affinity between violence and authoritarianism (see especially Médard 1991) towards definitions that function more as typologies built upon criteria of "who governs" (see, for instance, Geddes 2003 and Geddes 2004). Some authors, such as Svolik, nonetheless still highlight the continued importance of violence, though often as a background feature: "political power in dictatorships, even when nominally exercised through political institutions, must be ultimately backed by a credible threat of violence (Svolik 2009: 479)". It has also been argued that violence is a counter-productive strategy, especially when used indiscriminately: if an individual cannot avoid a regime's violence by remaining inactive, he or she is much more likely to join the opposition (Zahar and Saideman 2008; Kalyvas 2006; Cai 2008). A regime can therefore end up threatening itself: "Repression may work in the short run, as it raises the cost of dissent. But dissent delayed can be much stronger and more violent (Saideman et Zahar 2008:11-12)".

Furthermore, authoritarianism that uses too high a level of violence exposes itself to international sanctions that might endanger the regime through their economic effects (see, for instance, Brownlee 2002). This idea of violence as a double-edged sword can be linked to the debate in the literature on civil wars between proponents of an approach that describes violence as a form of hubris and authors who consider it to be instrumental: that is, something actors can use to reach their political or military goals (Valentino 2014). As De Waal explains, both cases do coexist in a specific political marketplace that is defined as "a system of governance run on the basis of personal transactions in which political services and allegiances are exchanged for material reward in a competitive manner" (De Waal 2016: 1). Sometimes, violence will be used as a tool to enhance someone's position, and sometimes it will "arise from error" (De Waal 2016: 3), when one participant misjudges the rivals or the market.

In order to move beyond these debates, there is a need for more case studies that highlight the exact mechanisms by which violence and authoritarian resiliency are connected. It may be especially fruitful to connect the use of violence, whatever form it may take, to other resiliency factors that are investigated in the literature. Gerschewski, for instance, has provided a model of the 
interrelations between what he calls the "three pillars of stability" - legitimation, repression and co-optation - demonstrating how one can reinforce the other (Gerschewski 2013), and yet his use of the concept of repression places violence in the form of civil war outside his framework. Indeed, most research on authoritarianism, including those I have quoted above, addresses violence by referring to repression and forgetting about civil war, despite the fact that the line separating these two phenomena is often blurred. Here, I propose to consider civil war as a form of violence that may play the same role as repression in an authoritarian context, as both forms of violence can overlap. Civil wars, according to Kalyvas, are a type of "armed combat within the boundaries of a recognized sovereign entity between parties subject to a common authority at the outset of the hostilities" (Kalyvas 2006: 5). They are complex processes involving micro and macro struggles. One of the factions is usually the State's armed forces, which are part of a broader security apparatus that includes the secret services and multiple police organizations. While the latter are often considered to be the force that implements repression, the roles are not usually as clear-cut, just as the transition from a local insurrection that can be repressed to a full-blown civil war that needs to be fought is more a matter of a political framing process than it is a mechanical one. Civil war, I argue, is both an externality of authoritarian politics and a governance strategy in itself, as it can lead to transformations within the winning coalition.

\section{The winning coalition}

The concept of the winning coalition has become somewhat ubiquitous in the North American literature on authoritarian politics. It has been borrowed from De Mesquita, Bruce and Siverson's research, in which they argue that every regime type needs to preserve the loyalty of the group to which it owes its power - the winning coalition - which is part of a larger group called the selectorate. In order to maintain this loyalty, leaders can choose to distribute either private goods, which are only given to members of the coalition, or public goods, which reach the totality of the selectorate by means of state policies. In democracies, the winning coalition is made up of the entire selectorate, as the leader is chosen through elections and universal suffrage. These regimes will therefore rely more on the implementation of public policies (De Mesquita, Bruce and al. 2003: 8). The opposite applies in authoritarian regimes, where the winning coalition will be limited to a small group.

Identifying with precision who is part of a winning coalition in authoritarian contexts can prove rather difficult, not only because the coalition evolves over time, but also because secrecy often prevails, and people who appear to have power may sometimes be puppets in the hands of others. The process of identifying a coalition may be easier in hybrid regimes that organize electoral processes, digged as they may be. Looking at who is allowed to participate and who is allowed to win can give an idea of the individuals and the broader 
category of people whose support is deemed necessary by the autocrat. It is also possible to look at the members of key institutions, although it would first be necessary to clearly identify where the locus of power lies. Another solution is to investigate co-optation practices, more specifically the distribution of goods and privileges, which again show whose loyalty is being nurtured. De Juan and Bank's research on which area of Syria still had electricity despite a period of power shortages highlights one of the many ways to identify if not who exactly the members of the winning coalition are, but at least the portions of the population that are favoured by the regime (De Juan and Bank 2015). Finally, it is important to incorporate the dynamic dimension of these coalitions into our analysis. Authoritarian regimes do not always rely on the same strategy or the same groups to maintain power. As they are confronted with challenges, both internal and external, autocrats who are able to have a fluid coalition, one that can evolve to respond to these challenges, are best placed to avoid being overthrown. Indeed, the transformation of many regimes into hybrid regimes signals this capacity to retain power through an ability to adapt.

The argument presented here is that in the case of Sudan, the war in Darfur presented a challenge that was overcome because of the regime's ability to transform its winning coalition. This was not done as a response to the war, however; it was achieved through the war itself, meaning that there is a strong congruence between strategies implemented to win wars and resiliency strategies. Whether these strategies achieve their aims is not necessarily relevant here, as my purpose is not to reconstruct the connection between actors' supposed goals and their "end results" a posteriori ${ }^{3}$, but to investigate the processes in order to highlight certain "situational logics" (Dobry 2007). Therefore, while I recognize the capacity of actors to actually devise strategies, I also take into account the possibility that these strategies may have an impact on processes other than the ones they were intended to influence.

\section{FIGHTING THE WAR IN DARFUR}

The root causes of the conflict: the convergence of micro and macro struggles

This civil war, which officially started in 2003, is still under way, despite the fact that a peace agreement - the Doha Document for Peace in Darfur (DDPD) - was signed in 2011. It is not my purpose here to dwell on the sources of the conflict, which are especially intricate, but I will attempt to offer a quick overview of the events that I hope will do justice to this

3. For a thorough critique of analyses that focus on actors' intentionality and their depiction of the relationship between agents and structures, see Dobry 2007. 
complexity. While Darfur only became the theatre of a full-blown civil war in 2003, the roots of the conflict go back to the development policies implemented since independence in 1956, which have marginalized the region. Tensions reached new heights in the 1980s, when Darfur was affected by drought. This was nothing new in itself, but it was combined with a national economic crisis that crippled the advance of Darfur's commercial economy, which had been progressing in preceding decades (De Waal 1989: 78). This situation resulted in population movements from one area of Darfur to another, as well as to other parts of the country. Most importantly, nomadic Arabs $^{4}$ and members of the Zaghawa group travelled towards less affected areas such as Jebel Mara. Disputes multiplied as "movements to other dars ${ }^{5}$ and the lack of respect for the traditional system of organizing this movement led to confrontation" (El-Battahani 2009: 46). Faced with growing tensions, many groups began to arm themselves and build their own militias (El-Battahani 2009: 46). It is important to underscore that these quarrels did not systematically oppose Arabs and non-Arabs, and that the ethnic groups that populate Darfur should not be considered to be completely homogeneous communities. As a matter of fact, many of the actors in the conflict straddled the borders between different identities quite easily. Nonetheless, various Arab groups came together at the end of the 1980s, uniting for a war against the Fur (1987-1989). They formed a political block called the Arab Gathering that was influenced by the pro-Arab ideology that was being propagated by the Libyan government at the time (de Waal 2004: 720). This is this period during which the Janjaweed started to appear as a more or less cohesive group, the word itself traditionally referring to gangs of outlaws from neighbouring Chad (Flint and de Waal 2008: 36). According to Mamdani, the Janjaweed began as an armed militia supplied by the Arab camel nomad groups who formed a minority within the organization (Mamdani 2010: 231).

What ignited the spark at a local level in 2003 was the fact that certain nomadic groups were failing to respect the traditional migration routes that had been agreed with the farmers -mainly Fur, in this case - under the supervision of the local authorities (interview, Darfur Regional Authority (DRA) member, Khartoum, March 10 2015). The incident quickly escalated into killings and raids, and it was when these small-scale quarrels intersected with national politics that they turned into a full-blown civil war. The appearance of two movements that began to articulate their grievances in terms similar to the SPLM/A's discourse played a major role in this process. They were a response to the longstanding dismissive attitudes and marginalizing policies

4. This term and others referring to various identity categories and groups are commonly used in the literature on Darfur, but should not be considered from an essentialist perspective, as they are historical and political constructs (Vezzadini 2011). 5. "Dars" is the name given to a tribe's homeland in Darfur. 
that had been implemented by the centre since colonial times and were then pursued by al-Bashir's regime (El Battahani 2009: 55). The first, the Sudan Liberation Movement/Army (SLM/A), had the support of the SPLM/A, and was composed mostly of Zaghawa and Fur and to a lesser extent of members of the Masalit, Beri, and Meido groups. The appearance of the second movement, the Justice and Equality Movement (JEM), was related to struggles within the regime's winning coalition.

In 1999, the alliance between the Islamists led by Turabi and factions of the military led by Bashir came to an end. The policies promoted by the NIF were unsustainable, especially because Turabi's insistence on making Sudan the centre of a global Islamist revival movement ended up isolating the country on the international stage (Marchal and Messiant 1995). Even its closest allies, the Saudis, became wary of it when the government welcomed Osama Ben Laden to Khartoum. As funding from donors and international organizations dried up and embargos were implemented, Sudan's economic situation became dire. In 1999, Turabi made his move to become the elected leader of the nation, and attempted to sideline Bashir. It did not work. Bashir used his hold on the army to exclude Turabi and his followers from the political game, and Turabi was placed under house arrest. But he did not disappear from the national stage completely : he created a new party, the Popular Congress Party (PCP), which joined the ranks of the opposition (Burr and Collins 2003; Ahmed 2009). This marginalization of the Islamist old guard fuelled the conflict in Darfur. Displeased with the situation, members of the PCP generated unrest in the western provinces in order to destabilize the regime, and though Turabi denies it, it is said that he is behind the creation of the JEM, or is at least one of its main sponsors (El Battahani 2009: 66; Flint and de Waal 2008).

Both these movements contributed towards taking the conflict to a new level, as their grievances were actually a criticism of Sudanese governance overall. They protested against the marginalization of the region, and demanded improved distribution of wealth and power. In this attempt to address national-level issues, they downplayed the importance of ethnic divisions (Flint and de Waal 2008: 16). It is also probably no coincidence that these movements appeared at a time when the negotiations between the SPLM/A and the government had begun to gain momentum. Some Darfuri politicians may have thought the moment was right to present similar claims, as the negotiations might be a sign the regime had been weakened.

\section{The Janjaweed as the cornerstone of the government's strategy}

The two rebel movements, especially the SLA/M, quickly achieved their first successes on the ground. To counter them, the government decided to recruit militias from among the Arab groups, relying on a strategy the regime - but also the preceding ones, including during the democratic interlude (1986-1989) - had already used in the south (Flint and de Waal 2008: 
23). This had the advantage of allowing the regime to argue on the international stage that it was clearly not fighting a war in Darfur. This form of sub-contracting was also a cheap way to fight the war, at a time when the government's finances were strained by a lengthy conflict in the south that had reached a stalemate: retirement and other benefits do not need to be offered to militiamen as they do in the case of members of the Sudan Armed Forces (SAF), and no contracts are signed (interview, retired army officer, Khartoum, April 28 2015). In order to lead this war on its behalf, the government identified key personalities, of whom the main - and most infamous - one was Musa Hilal. The sheikh of the nomadic Arab Mahameed group, Hilal established his headquarters in the area of Misteriha in North Darfur in the mid-1990s, leaving Aamo, the town where his father had established himself in 1973 and used to hold court. In little more than a decade, Misteriha became a military base where Hilal's men were trained (Flint and de Waal 2008: 38). He had already been involved in the fighting before the conflict broke out, and had ties with the then-Governor of North Darfur, General Abdallah Safi el Nur. He had also been a leader of the Arab Gathering, a coalition of Arab groups, since the 1990s (HRWA 2005: 12). The next Governor, Lieutenant-General Ibrahim Suleiman Hassan, apparently found Hilal too troublesome, and concerned about the increasing tensions in Darfur, he detained him and sent him to prison in Port Sudan, on the other side of the country. According to Human Rights Watch, this led to a decline in the number of attacks committed by the Janjaweed (HRWA 2005: 13).

After SLA/M's initial victories, however, Hilal was liberated, and Suleiman was removed from his post by the President. The Sheikh settled in the Kebkabiya area, where he organized meetings during which he ordered his fellow tribesmen to attack non-Arab villages (HRWA 2005: 12-13). Although exactly what was promised to the fighters cannot be known with certainty, the fighting offered them the opportunity to make what they were trying to take since the 1980s theirs: land. This pressing issue had been the reason behind attacks from one group or another in many parts of Darfur since the 1960s, following waves of migration from the northern areas, which were affected by drought, and from neighbouring Chad that increased the pressure on available farmland (Abdul-Jalil and Unruh 2013: 166-167). The issue was exacerbated by various land reforms, such as the 1970 Unregistered Land Act, which stated that all land that was not registered at that date belonged to the government, and the abolition of the custom-based Native Administration in 1971. These reforms allowed the newcomers to claim land rights, disregarding the customary rules that had previously regulated the allocation of land among groups (Abdu-Jalil and Unruh 2013: 166-167). The government's intervention in the division of Dars in Western Darfur in the 1990s increased tensions, leading to "a devastating ethnic conflict and widespread insecurity" (Abdul-Jalil 2006: 16), and a state of emergency was declared in Western Darfur from 1995 to 1999. As Kalyvas reminds us, the relationship between the national framing of 
a civil war and people's motivations on the ground is a complex one, as more often than not "individual and local actors take advantage of the war to settle local or private conflicts often bearing little or no relation to the causes of the war or the goals of the belligerents (2003: 475-476)". Darfur is a textbook case in this respect: not only did the JEM and SLA/M frame a fight that had its origins in very local situations in terms of a national governance issue, but there was also a mutually beneficial alliance between certain Arab groups and the government. It is important to mention, however, that not all groups contributed to the Janjaweed, and that many people opposed this strategy. In any event, from then on, the Janjaweed began to act in coordination with government forces, which provided weapons and logistical support.

Testimonies collected by Human Rights Watch describe the attacks as joint army-militia endeavours: "In many cases, villages were first heavily bombed, then the Janjaweed and army ground forces moved in, again with aerial support, to ensure the "cleaning up" of any remaining civilian presence (2005: $19)^{\prime \prime}$. Antonov aircraft, helicopters and Sudanese military vehicles were regularly spotted alongside the camel-riding Janjaweed (HRWA 2005, 16). Both sides have denied any such coordination. Hilal blamed the SAF for the attacks, claiming he was "only a coordinator for the Popular Defence Force", as "training, uniforms, and guns are the responsibility of the military people" (HRWA 2005: 19). The government, on the other hand, denied its involvement with the Janjaweeed (de Waal 2004: 724). Despite these claims, the relationship between the regime and Hilal was obvious, and his frequent round-trips to Khartoum left few doubts. According to Tubiana, the relationship between the Janjaweed and the central government involved three levels of authority:

the local tribal leader, Hilal, who was - at least at the beginning of the conflict - not much more than a mere underling;

local politicians and/or military men from Darfur, who were closer to the epicentre of power in Khartoum.

the regime hardliners (2005: 176).

One of the people whom many consider to be responsible for organizing the Janjaweed at a higher level is Ahmed Haroun, who was Minister of the Interior at the time. He is currently the subject of a warrant issued by the International Criminal Court - as is Bashir - for his involvement in the war.

\section{THE JANJAWEED AND THE SECURITY APPARATUS}

\section{A counterbalancing strategy}

As mentioned previously, the government's reliance on militias to fight its war in Darfur is not a new strategy. It had already been used in the South, fuelling divisions within the rebel movements by pitting one group against the other, and while Bashir's regime does have a long history of creating militias, 
the same policy was also implemented by Sadiq al-Mahdi in 1986, when he "established militias to counteract the NIF militia and to serve in the war against the SPLA" (Salih 2005: 8-9). This process of creating militias can be interpreted as part of a counterbalancing strategy. As early as 1989, the new leadership had created a paramilitary militia called the People's Defense Force (PDF). This was arguably Turabi's idea, the aim being to create an armed force that would be loyal to the NIF, as opposed to the SAF, which, Turabi apparently claimed, was too secularized to be completely devoted to his project (Burr and Collins 2003: 193). It is therefore necessary to understand the appearance of the PDF in the broader context of the regime's inside politics, with Turabi and Bashir's dual governance. The early years of the regime also saw the rising importance of the security services. Well-trained and well-financed, the presence of the NISS is pervasive in the lives of many Sudanese. While it is very difficult to find reliable information about the inner workings of the regime, even more so in the case of the security apparatus, it is said that the NISS is not only completely independent from the armed forces but also the one organization that is truly the strong arm of the regime (interview, professor, Khartoum, March 25 2015). According to one of the interviewees, during the JEM's attack on Omdurman in 2008, the SAF ended up being caught between the rebels and the NISS's forces, who launched their attack without any consideration for the military and decimated their ranks (interview, retired army officer, Khartoum, April 28 2015). In 2011, to add to these internal divisions, Bashir announced the creation of a small force called the Strategic Unit, which was to be in charge of crushing any revolt against the regime (International Crisis Group 2011: 14). This fragmentation of the security organs goes even further, as "the police are broken into regular, public order and popular police, the central contingency force and transhumance route police. The Jaali section of the upper elite reportedly has a private force (the "Precious Stones") under Bashir's command" (International Crisis Group 2011: 14). One actually has only to wander around Khartoum a little to see this fragmentation incarnated in the many different uniforms that can be spotted along the streets.

This can be interpreted in different ways. While some might relate it to internal power struggles, with each faction arming itself to the teeth, the idea that it might be a sign of the regime's weakness needs to be approached carefully. According to some of the interviewees, these factions are part of the regime's policy of deceit. Referring to an attempted coup in 2014, one stated that the perpetrators were later released because "they are part of the system (interview, rebel leader, Khartoum, April 29 2015)", while another explained that:

"All these people who are ruling the country are united, but they behave as if they are divided... It is a kind of deception, the message that there is a hope they are going to collapse. But this collapse, which might come, as a consequence of their fragmentation or conflicts, is itself being used to intimidate the Sudanese or 
the international community. If we are to fight each other, this would bring hell to Sudan. And not only Sudan, to the whole region". (interview, professor, Khartoum, March 22 2015)

Another interpretation of the fragmentation of the security apparatus, and the one favoured here, is that this is part of a counterbalancing strategy that is not, however, necessarily consciously implemented as such. Recent literature has attempted to describe the strategies dictators use to avoid coups, which are named coup-proofing strategies. The army in particular is looked upon suspiciously, as it is the actor that has the means to implement a coup. One of the most common practices used is counterbalancing, which consists in dividing the army into different organizations, for instance by creating paramilitary forces (Belkin and Schofer 2005; Lee 2005; Powell 2012). These groups will then compete with each other, for funding, for example. The creation of the PDF, the reinforcement of the NISS, and the subsequent creation of different bodies all contribute towards curtailing the power of the army, while at the same time making sure that no organization becomes completely overbearing. While it is true that the extent of the NISS's powers seems to contradict this theory, and that this interpretation needs more investigation, it is not unthinkable that the process of counterbalancing might be derailed as the years go by, with one organization taking the lead over the others. At the same time, given the near impossibility of knowing what happens within these organizations, it may very well be true that the NISS is not as omnipotent as it is thought to be.

\section{From expandable allies to last bulwark of the regime}

In any event, the Janjaweed, who became the government's allies during the conflict, are acquiring importance within the whole apparatus, and gaining power to a point where they may actually be counterbalancing that of the NISS, even though the relationship between the two remains unclear. According to one interviewee, it is the NISS that orchestrated the repression of the demonstrations that took place in September 2013 in many large cities, with the Janjaweed executing the orders (interview, rebel leader, Khartoum, April 29 2015). The Janjaweed have actually been brought in from Darfur to be stationed on the outskirts of Khartoum. While some claim that they are only there for training purposes (interview, retired army officer, April 28 2015), others argue they are there to stay, a claim that seems to be corroborated by recent events. Indeed, according to the Enough Project $\mathrm{NGO}$, the Janjaweed were reorganized in 2014, and a part of them was transformed into a new organization, the Rapid Support Forces, led by Mohamed Hamdan Daglo (also known as Hemeti), and integrated into the NISS (Kumar and Ismail 2014). According to Ahmed Hussain Adam (2014), in May 2014, "Mr Bashir used the force in Khartoum - not for the first time, but on an unprecedented scale - deploying at least 3,000 of the RSF's 
estimated 10,000 fighters in the capital and placing it under the direct command of the NISS". This situation has fuelled tensions in these neighbourhoods, with reports of clashes between the local population and the repackaged Janjaweed (Sudan Tribune 2014; Sudan Tribune 2015). Analysing the government's composition after the 2015 elections, Ali and Hussain Adam (2015) further argue that the Janjaweed are now one of the main pillars of the regime. The members of this government "are either army generals or NISS officers, or maintain strong connections with the NISS, the SAF, and the Janjaweed". Hemeti secured some key positions for his relatives and supporters at different levels of the government, meaning that "Hemeti and his Janjaweed militia (the RSF) have been given the upper hand in the new government and crowned as Bashir's personal army" (Ali and Hussain Adam 2015). This indeed raises the question of the control of the NISS over the Janjaweed, which seems more and more in doubt.

Undoubtedly the Janjaweed, or at least a part of them, are becoming an increasingly vital part of the winning coalition. The way this militia is used also reflects the regime's governing techniques. According to a Professor at the University of Khartoum, one of the devices the regime is using to ensure its survival is intimidation, which for the government means showing the Sudanese that if the regime falls, the situation is going to become even worse, a threat that is especially effective with the rise of ISIS in neighbouring countries. Here, intimidation is intrinsically related to the use of coercion, with the idea that "if we [the regime] are threatened, we are going to destroy everything, everything is going to explode. So a lot of Sudanese now (...) they will tell you that yes, it is better" (interview, professor, Khartoum, March 22 2015). The deployment of the Janjaweed serves a specific purpose here: it sends a message that if people try to oppose the regime in ways that are considered to be too overt, they will pretty much let the dogs out, and if they are toppled, these people will have no one to control them and all hell will break loose. The government's reaction when popular demonstrations took place in Khartoum in 2013 therefore served as a sort of reminder that the status quo is preferable:

The first day there is very minor response from the government. On the second day, even some police and military began to send cordial messages to the people on the streets. But on the third day, as the President himself put it in the TV, they have recourse to what they called... They said for the first day we allowed the people to express their... and the second day we saw that they began to destroy public and private properties. And that is why, on the third day we switch to...the Janjaweed, with their land cruisers, with these ... and with guns and they...250 people died. Students, workers and the like. And that is how they put... and this was a very strong message. We are going to kill as much as possible if you continue to be on the streets. They are using this device very effectively and a lot of people on the street, ordinary people, they do believe that this government is bloody and they can kill (interview, professor, Khartoum, March 22 2015). 


\section{CONCLUDING REMARKS: AMBIGUOUS ALLIES}

Managing a winning coalition is a tricky business. One has to balance factions to give them power with one hand, while making sure with the other that they do not start to feel too emboldened, to the point of fomenting a coup. As they reach the epicentre of power and make themselves less and less expendable, the Janjaweed's leaders may start to get ideas the regime might find distasteful. This seems to be the case with Musa Hilal, who began his transformation from local leader to a politician of national stature at the end of the last decade. In 2008, he was nominated as a special advisor to the President. Then, after gaining a certain amount of prominence, he defected from the NCP in 2014 and launched his own party, the Sudanese Awakening Revolutionary Council (SARC) (International Crisis Group 2015: 11). He simultaneously made a decisive move to take control of gold mining in the Jebel Amer area of North Darfur. In April 2014, the Sudanese Ministry of Minerals awarded the concession for the exploration of gold deposits in the area to the MAM Group, a Sudanese industrial group, a decision to which Hilal replied by warning the company not to come without the agreement of the area's local and tribal authorities (Radio Dabanga 2014a). In fact, he had actually created a management board for the mine. It was said during a meeting that "the responsibility for protection of the gold mine lies with the management board, and not with the regular forces" (Radio Dabanga 2014b). On this occasion, Hilal reportedly called on the Sudanese to fight the regime (Tubiana 2014; Radio Dabanga 2014b). Relations with the regime became strained, and looked to be beyond repair when he gave the regime an ultimatum in early 2015: either the government responded to the SARC's demands - which were probably about the gold, although little specific information is available - or it would face unspecified consequences. He then instructed his followers to boycott and obstruct the election in Darfur (Sudan Democracy First 2015). In February, however, the government apparently accepted his demands and signed a memorandum of understanding with the SARC. Hilal finally endorsed Bashir's candidacy and even mobilized his troops, this time to pressure voters. Perhaps in order to further confirm his loyalty to the regime, the long-time governor of North Darfur, Osman Youssif Kibir, whose troops fought Hilal's, has recently been dismissed. His daughter's wedding to Idriss Deby, the Chadian President and a regional power broker, in 2012 might have also reinforced Hilal's position.

Hilal's behaviour demonstrates the porosity of the insider/outsider dichotomy, and how easily these defining lines can be crossed. More than this, "border-straddling" is a fully-fledged political strategy in Sudan: Hilal is not the first personality to blithely switch sides in order to pressure the government into meeting his requests. This undoubtedly ties in with the idea that factions within the regime are not much more than power devices created for the purpose of cutting a larger slice of the national cake. In the end, no faction 
is interested in overthrowing the system, because each benefits from the marginalizing power structure that forms the cornerstone of the regime. It should not be forgotten, however, that this structure did not emerged suddenly in 1989: it is firmly rooted in decades of self-serving, inequality-producing politics that go back to the colonial era (see, for instance, Ahmed 2004; Deng 2010; Vezzadini 2011).

For now, the Janjaweed's rise to prominence has not turned into a cautionary tale, and decades of deceitful politics should make any analyst of Sudanese politics wary of spotting signs of the regime's weakness in any kind of internal squabble. If we analyse the Janjaweed's positioning and trajectory - and more specifically those of their leaders - we can see how the time of the civil war has been exploited by the regime to empower new allies, or to be more precise, old ones who had been at the periphery of the regime's core. This goes to demonstrate not only the flexibility of the winning coalition in Sudan, but also the stability of the regime's survival strategies, which rely on violence and a capacity to find opportunity in any challenge. The war is not necessarily a moment distinct from that of "normal politics", as the same dynamics persist: counterbalancing is implemented, loyalties are bought, and specific groups of people are removed from influential positions. The fact that war may become politics as usual may nonetheless have unexpected consequences, as people who have committed terrible abuses are never held responsible, and are even rewarded. This is very clear not only when one looks at the Janjaweed, but also when one studies the rebels. Through the power-sharing devices that are a part of every peace agreement nowadays, some rebels have gained access to prominent positions within the government. Furthermore, peace agreements are negotiated and signed one after the other, with the latest one integrating the groups that spoiled the previous one. This demonstrates that the use of violence is an efficient means of having one's your demands met. Hence, at the local level, more and more groups and sub-groups have started to acquire weapons for themselves, having noted how power-sharing seems to work in Sudan (Bashir Ali Adi 2014). This process actually explains to a large extent not only why fighting is still under way in Darfur, but also why this situation does not threaten the government, since groups begin to fight each other for a share of power that in the end is always allocated by the government. Furthermore, this fragmentation means that the government can always find new allies by playing the "divide-and-conquer" game over and over again. Here, instability does not preclude authoritarian resilience: it fuels it.

\section{ACKNOWLEDGEMENTS}

The author wishes to thank the Centre for Social, Legal and Economic Studies in Khartoum for its financial and logistical support during the fieldwork this paper is based on. 


\section{BIBLIOGRAPHY}

Abdelwahid, M. 2008, The Rise of the Islamic Movement in Sudan (19451989). Lewinston, New York: Edwin Mellen Press.

Abdul-Jalil, M. A. 2006, "The Dynamics of Customary Land Tenure and Natural Resource Management in Darfur", Land Reform, Land Settlement and Cooperatives, no. 2: 8.

Abdul-Jalil, M. and Unruh, J. D., 2013, "Land Rights under Stress in Darfur: A Volatile Dynamic of the Conflict", War \& Society, vol. 32, no. 2: 156-81.

Ahmed, E., 2004, "L'Elite du Pouvoir au Soudan: Hégémonie et Recrutement Politique (1985-2000)." Bordeaux 4.

- 2009. "L'Islam Politique au Soudan", in R. Otayek and B. Soares, Islam, État et Société En Afrique, Paris: Karthala.

Ali, H. E., and Hussain Adam, A. 2015, "Bashir's Autocratic Regime Is Fighting for Its Survival." African Arguments. July 17. http://africanarguments. org/2015/07/17/bashirs-autocratic-regime-is-fighting-for-its-survival-byhamid-e-ali-and-ahmed-hussain-adam/.

Baas, S. 2013, "Low-Intensity Conflict in Eastern Sudan: A Comparative Approach to the Development of Rebel Groups." Small Wars \& Insurgencies, vol. 24, no. 3: 518-35.

Bashir, A. M. 2014, "Power-Sharing in Southeast Darfur. Local Translations of an International Model", in A. Behrends, S. J. Park, and R. Rottenburg, Travelling Models in African Conflict Management: Translating Technologies of Social Ordering, Africa-Europe Group for Interdisciplinary Studies 15746925, Volume 13, Brill.

Belkin, A. and Schofer, E. 2005, "Coup Risk, Counterbalancing, and International Conflict." Security Studies, vol. 14, no. 1: 140-77.

Burr, M., and Collins, R. 2003, Revolutionary Sudan: Hasan Al-Turabi and the Islamist State, 1989-2000. Brill.

- 2006, Darfur: The Long Road to Disaster. African History. Markus Wiener.

Cai, Y. 2008, "Power Structure and Regime Resilience: Contentious Politics in China", British Journal of Political Science, vol. 38, no. 3: 411-32.

De Juan, A., and Bank, A. 2015, "The Ba'athist Blackout? Selective Goods Provision and Political Violence in the Syrian Civil War", Journal of Peace Research, vol. 52, no. 1: 91-104.

De Mesquita, B., Smith, A., Siverson, R., and Morrow, J. 2005, The Logic of Political Survival, MIT Press.

Deng, F. 2010, New Sudan in the Making?: Essays on a Nation in Painful Search of Itself, Red Sea Press.

De Waal, A. 1989, Famine That Kills, Oxford University Press.

2004, "Counter-Insurgency on the Cheap", Review of African Political Economy, vol. 31, no. 102: 716-25. 
2016, "Introduction to the Political Marketplace for Policymaker", JSRP Policy Brief, The Justice and Security Research Programme.

Dobry, M. 2007, "Ce Dont Sont Faites les Logiques de Situation », in P. Favre, O. Fillieule and F. Jobard, L'atelier Du Politiste. Théories, Actions, Représentations, Recherches, Paris: La Découverte.

El-Battahani, A. 2009, "Ideological Expansionist Movements versus Historical Indigenous Rights in the Darfur Region of Sudan: From Actual Homicide to Potential Genocide", in S. Hassan and C. Ray, Darfur and the Crisis of Governance in Sudan. A Critical Reader, Ithaca, New York: Cornell University Press.

Flint, J., and A. de Waal 2008, Darfur: A New History of a Long War, African Arguments, Zed Books.

Geddes, B. 2003, Paradigms and Sand Castles: Theory Building and Research Design in Comparative Politics, University of Michigan Press.

_ 2004, "Authoritarian Breakdown." Manuscript. Department of Political Science, UCLA.

Gerschewski, J. 2013, "The Three Pillars of Stability: Legitimation, Repression, and Co-Optation in Autocratic Regimes", Democratization, vol.20, no. 1: 13-38.

Hassan, S. M., and C. E. Ray 2009, Darfur and the Crisis of Governance in Sudan: a critical reader, Ithaca, New York: Cornell University Press.

HRWA 2005, "Entrenching Impunity: Government Responsibility for International Crimes in Darfur", vol. 17, Human Rights Watch.

Hussain Adam, A 2014, "In Sudan, the Janjaweed Rides Again", The International New York Times, July 16. http://www.nytimes.com/2014/07/17/opinion/ in-sudan-the-janjaweed-rides-again.html?_r=2.

International Crisis Group 2015, "The Chaos in Darfur", no. 110. Africa Briefing.

2011, "Divisions in Sudan's Ruling Party and the Threat to the Country's Future Stability", no. 174, Africa Reports.

Kalyvas, S. 2003, "The Ontology of 'Political Violence': Action and Identity in Civil Wars." Perspective on Politics, vol.1, no. 3: 475-94.

- 2006, The Logic of Violence in Civil War, Cambridge Studies in Comparative Politics, Cambridge University Press.

Kumar, A., and Ismail, O. 2014, Janjaweed Reincarnate: Sudan's New Army of War Criminals, The Enough Project.

Lee, T. 2005, "Military Cohesion and Regime Maintenance Explaining the Role of the Military in 1989 China and 1998 Indonesia", Armed Forces \& Society, vol.32, no. 1: 80-104.

Mamdani, M. 2010, Saviors and Survivors: Darfur, Politics, and the War on Terror, Three Rivers Press.

Marchal, R., and Messiant, C. 1995, Éléments d'une Sociologie du Front National Islamique Soudanais. Fondation nationale des sciences politiques. 
Zahar, M-J., and Saideman, S. 2008, "Causing Security, Reducing Fear: Deterring Intra-State Violence and Assuring Government Restraint", in M-J. Zahar and S. Saideman, Intra-State Conflict, Governments and Security: Dilemmas of Deterrence and Assurance, Routledge.

Médard, J-F. 1991, "Autoritarismes et Démocraties en Afrique Noire", Politique Africaine, no. 43: 92-104.

Picard, E. 2008, "Armée et Sécurité au Coeur de I'Autoritarisme", in O. Dabène, V. Geisser and G. Massardier, Autoritarismes Démocratiques et Démocraties Autoritaires au XxI siècle: Convergences Nord-Sud, Paris: La Découverte.

Powell, J. 2012, "Determinants of the Attempting and Outcome of Coups d'Etat", Journal of Conflict Resolution, vol. 56, no. 6: 1017-40.

Prunier, G. 2005, Darfur: The Ambiguous Genocide, Ithaca, New York: Cornell University Press.

Radio Dabanga. 2014a, "Darfur Gold Concession Winner Warned off by Hilal", April 18.

_ 2014b, "Musa Hilal's Council Forms 'Jebel'Amer Administration', Calls for Intifada in Sudan", December 16. https://www.dabangasudan.org/en/ all-news/article/musa-hilal-s-council-forms-jebel-amer-administration -calls-for-intifada-in-sudan.

Salih, M. A. 2005, Understanding the Conflict in Darfur, Centre of African Studies.

Sudan Democracy First 2015, “Musa Hilal's 'Awakening': Khartoum's Worst Nightmare?", Sudan Tribune, April 22.

Sudan Tribune 2014, "Clashes Erupt in North Khartoum between Villagers and RSF Militia", December 27.

2015, "Sudan's RSF Militia Blocks Highway in Khartoum for Several Hours," September 6.

Tripp, A. M. 2004, "The Changing Face of Authoritarianism in Africa: The Case of Uganda", Africa Today, vol. 50, no. 3: 3-26.

Tubiana, J. 2005, "Le Darfour, Un Conflit Identitaire?", Afrique Contemporaine, vol.214, no. 2: 165-206.

2006, "Le Darfour, Un Conflit Pour La Terre?", Politique Africaine, vol.101, no. 1: 111-31.

201, "Out for Gold and Blood in Sudan." Foreign Affairs. https://www. foreignaffairs.com/articles/sudan/2014-05-01/out-gold-and-blood-sudan.

Valentino, B. 2014, "Why We Kill: The Political Science of Political Violence against Civilians", Annual Review of Political Science, vol. 17: 89-103.

Vezzadini, E. 2011, "Genealogies of Racial Relations: The Independence of South Sudan, Citizenship and the Racial State in the Modern History of Sudan", Association of Concerned Africa Scholars, vol. 86 (November). 